INTERNATIONAL JOURNAL
PHARMACEUTICAL SCIENCES
RESEARCH
REDT

Received on 13 April, 2017; received in revised form, 14 June, 2017; accepted, 25 July, 2017; published 01 December, 2017

\title{
DEVELOPMENT AND VALIDATION OF A STABILITY INDICATING HPLC METHOD FOR THE SIMULTANEOUS ANALYSIS OF ISOPROPAMIDE AND TRIFLUOPERAZINE IN FIXED-DOSE COMBINATION TABLETS
}

Masimukku Siva Kishore ${ }^{* 1,2}$ and Chintala Rambabu ${ }^{1}$

Department of Chemistry ${ }^{1}$, Acharya Nagarjuna University, Guntur - 522510, Andhra Pradesh, India. Department of Chemistry ${ }^{2}$, K. B. N. P. G College, Vijayawada - 520001, Andhra Pradesh India.

Keywords:

Isopropamide, Trifluoperazine, RP-HPLC, Method development and Validation. Correspondence to Author: Masimukku Siva Kishore

Assistant Professor, Department of Chemistry, K.B.N. P. G College, Vijayawada 520001, Andhra Pradesh India.

E-mail: siva.masimukku@gmail.com

\begin{abstract}
A simple, precise isocratic stability indicating RP-HPLC method was developed for the determination of isopropamide and trifluoperazine in pure and its pharmaceutical formulations. In the developed method, methanol, acetonitrile and water in the ratio of 40:30:30 (v/v) as mobile phase and Waters C-18 (250mm x 4.6mm, $5 \mu \mathrm{m})$ column as stationary phase were used. The flow rate and detection wavelength were $0.9 \mathrm{~mL} / \mathrm{min}$ and $240 \mathrm{~nm}$ respectively. The method was validated as per ICH guidelines for specificity, linearity and range, precision, accuracy, robustness, solution stability, limit of quantification and limit of detection. The stability-indicating capability was established by forced degradation experiments. The results of all the validation parameters were well within their acceptance limits and also the degradation products formed during different stress conditions in stability studies were separated from both drugs and also from individual degradation products. This validated method was applied for the simultaneous estimation of isopropamide and trifluoperazine in commercially available formulation sample.
\end{abstract}

INTRODUCTION: Trifluoperazine belongs to phenothiazine chemical class and is a typical antipsychotic drug used for treating schizophrenia. It may also be used for the short-term treatment of certain types of anxiety ${ }^{1-3}$. It is believed to work by blockading dopamine $\mathrm{D}_{1}$ and $\mathrm{D}_{2}$ receptors in the mesocortical and mesolimbic pathways, relieving or minimizing such symptoms of schizophrenia as hallucinations, delusions and disorganized thought and speech $^{4-9}$.

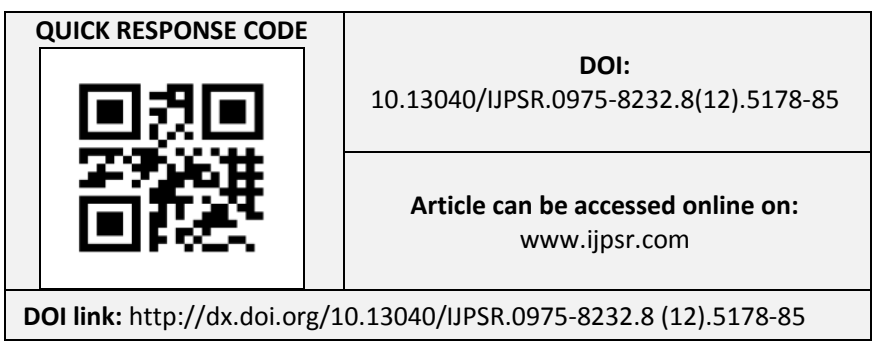

Isopropamide is a long-acting quaternary anticholinergic drug used for the treatment of peptic ulcer disease, in the relief of gastrointestinal (GI) and urinary tract disorders associated with smooth muscle spasm, in rhinitis, gastritis, hyperchlorhydria, functional diarrhea, irritable or spastic colon, pyloroduodenal irritability, pylorospasm, acute nonspecific gastroenteritis, biliary dyskinesia and chronic cholelithiasis, duodenitis, gastrointestinal spasm ${ }^{10}$.

The drug may also be used to treat genitourinary spasm. The drug works by inhibiting parasympathetic nerve impulses by selectively blocking the binding of the neurotransmitter acetylcholine to its receptor in nerve cells. The nerve fibers of the parasympathetic system are responsible for the involuntary movements of 
smooth muscles present in the gastrointestinal tract. Inhibition here decreases acidity and motility, aiding in the treatment of gastrointestinal disorders ${ }^{11}$.

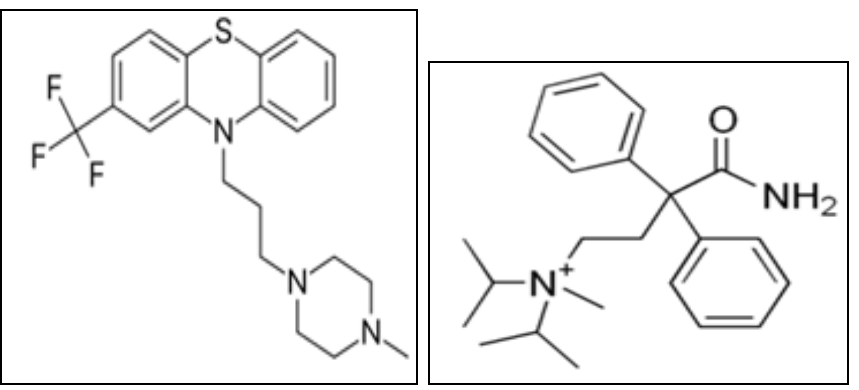

FIG. 1: CHEMICAL STRUCTURE OF TRIFLUO PERAZINE AND ISOPROPAMIDE

Literature review reveals that there are only two liquid chromatographic techniques reported for simultaneous determination of trifluoperazine and isopropamide in pharmaceutical dosage forms ${ }^{12,13}$. There are few chromatographic $14-18$ and spectrophotometric $19-23$ methods reported for trifluoperazine, isopropamide individually or in combination with other drugs. Till now, no stability indicating RP-HPLC method has been reported with trifluoperazine and isopropamide and hence forms the basis of the study.

\section{CHEMICALS AND MATERIALS:}

Methanol, acetonitrile, water (Merck, Mumbai, India) were of HPLC grade, while sodium perchlorate used for the preparation of mobile phase was of analytical grade (Merck Specialties Private Limited, Mumbai, India).The membrane filters $0.22 \mu \mathrm{m}$ and syringe filters $0.45 \mu \mathrm{m}$ for the analysis were supplied by Millpores (Millipores Ltd. Banglore). Denver electronic analytical balance (SI-234). was used to weigh the standard and sample drugs. Analytically pure isopropamide and trifluoperazine were obtained as gift sample from reputed pharmaceutical companies. Formulations of stelbid tablet containing a combination of trifluoperazine and isopropamide with labeled amount of $2 \mathrm{mg}$ and $5 \mathrm{mg}$ respectively were procured from local market.

Equipment: The liquid chromatographic procedures were carried out on PEAK chromatographic system equipped with LC-P7000 binary gradient pumps, with variable wavelength programmable UV7000 detector and Rheodyne injector with $20 \mu \mathrm{L}$ fixed loop. Chromatographic integration and processing was carried out on PEAK chromatographic software version 1.06. A Waters C-18 (250mm x $4.6 \mathrm{~mm}, 5 \mu \mathrm{m})$ column was used as a stationary phase. Teccomp UV-2301 double beam UVVisible spectrophotometer was used to carry out spectral analysis and the data was recorded by Hitachi software. Standard and sample drugs were weighed by using Denver electronic analytical balance (SI-234).

Preparation of mobile phase: The mobile phase was prepared by mixing methanol: acetonitrile: water in the ratio of 40:30:30(v/v) and sonicated for $15 \mathrm{~min}$.Mobile phase was filtered through $0.22 \mu \mathrm{m}$ membrane filter. The $\mathrm{pH}$ of the mobile phase was found to be 5.6.

Preparation of standard solutions: A stock solution of trifluoperazine and isopropamide was prepared by dissolving $100 \mathrm{mg}$ of the standard drug in $100 \mathrm{~mL}$ volumetric flask with methanol individually. These solutions were sonicated for 15 min and filtered through mill pore filter paper with $0.45 \mu \mathrm{m}$ pore size. The aliquots of this solution were diluted accurately with mobile phase to get working standard solutions of trifluoperazine - 2$12 \mu \mathrm{g} / \mathrm{mL}$ and isopropamide in the concentration range of $5-30 \mu \mathrm{g} / \mathrm{mL}$.

Preparation of sample solution: 10 formulation tablets of isopropamide and trifluoperazine (Stelbid; Trifluoperazine - $2 \mathrm{mg}$ and Isopropamide - $5 \mathrm{mg}$ ) were powdered and the powder equivalent to $10 \mathrm{mg}$ of trifluoperazine was weighed accurately and was dissolved in $10 \mathrm{~mL}$ mobile phase. Then it was filtered and made up to $10 \mathrm{~mL}$ with same diluents to make $1000 \mu \mathrm{g} / \mathrm{mL}$ stock solution. From this by proper dilution, appropriate concentrations of the two drugs in the dosage form were prepared.

Method development: Various chromatographic conditions like mobile phase ratio, mobile phase solvents, column, $\mathrm{pH}$ of the mobile phase, wavelength of the detector etc. have been optimized in order to achieve separation and identification of trifluoperazine and isopropamide. Chromatographic conditions with best system suitability conditions were selected. The developed method was validated in terms of system suitability, specificity, linearity and range, precision, accuracy, limit of detection, limit of 
quantification, solution stability and robustness as per USP and ICH guidelines ${ }^{24-26}$.

Forced degradation studies: To perform the forced degradation study $50 \mathrm{mg}$ each drugs were subjected to acidic, alkaline, oxidizing, thermal and photolytic conditions. For acidic degradation the drug was heated under reflux with $0.1 \mathrm{M} \mathrm{HCl}$ at $80^{\circ} \mathrm{C}$ for $2 \mathrm{~h}$ and the mixture was neutralized. For alkaline degradation the drug was treated with 0.1 $\mathrm{M} \mathrm{NaOH}$ at $80{ }^{\circ} \mathrm{C}$ for $2 \mathrm{~h}$ and the mixture was neutralized. For degradation under oxidizing conditions the drug was heated under reflux with (30\%, v/v) $\mathrm{H}_{2} \mathrm{O}_{2}$ at $80{ }^{\circ} \mathrm{C}$ for $2 \mathrm{~h}$. For thermal degradation the powdered drug was heated to $70{ }^{\circ} \mathrm{C}$ for $48 \mathrm{~h}$. For photolytic degradation the powdered drug was exposed to sunlight for $48 \mathrm{~h}$. The placebo was also subjected to the same stress conditions to determine whether any peaks arose from the declared excipients. After completion of the treatments the solutions were left to return to room temperature and diluted with solvent mixture to furnish $30 \mu \mathrm{g} / \mathrm{mL}$ solutions. The purity of the drug peak obtained from the stressed sample was measured using UV detector and compared with the chromatogram of untreated drugs in tablet solution.

\section{RESULTS AND DISCUSSION:}

Method development: The RP-HPLC chromatographic conditions were optimized to get best resolution and peak shape. The selection of mobile phase was based on peak parameters like symmetry and theoretical plates. Symmetrical peaks with good separation (retention time for trifluoperazine is 4.4 and isopropamide is $5.9 \mathrm{~min}$ ) were obtained with reverse phase Waters C-18 $(250 \mathrm{~mm} \times 4.6 \mathrm{~mm}$, $5 \mu \mathrm{m})$ column. The mobile phase containing methanol, acetonitrile and water in the ratio of $40: 30: 30(\mathrm{v} / \mathrm{v})$ was used at a flow rate of $0.9 \mathrm{~mL} / \mathrm{min}$. The optimum wavelength for detection and quantification was at $240 \mathrm{~nm}$, at which good detector response was obtained for both the drugs. The results are given in Table $\mathbf{1}$ and the standard chromatogram was given in Fig. 2.

TABLE 1: OPTIMIZED CHROMATOGRAPHIC CONDITIONS FOR THE ANALYSIS OF ISOPROPAMIDE AND TRIFLUOPERAZINE

\begin{tabular}{ccc}
\hline S.no & Parameter & Results \\
\hline 1 & Mobile phase & Methanol: Acetonitrile: Water $40: 30: 30(\mathrm{v} / \mathrm{v})$ \\
2 & Wavelength & $240 \mathrm{~nm}$ \\
3 & Stationary phase & Waters C-18 $(250 \mathrm{~mm} \times 4.6 \mathrm{~mm}, 5 \mu \mathrm{m})$ column \\
4 & pH of mobile phase & 5.6 \\
5 & Flow rate & $0.9 \mathrm{~mL} / \mathrm{min}$ \\
6 & Pump mode & Isocratic \\
7 & Pump pressure & $10.7 \pm 5 \mathrm{MPa}$ \\
\hline
\end{tabular}

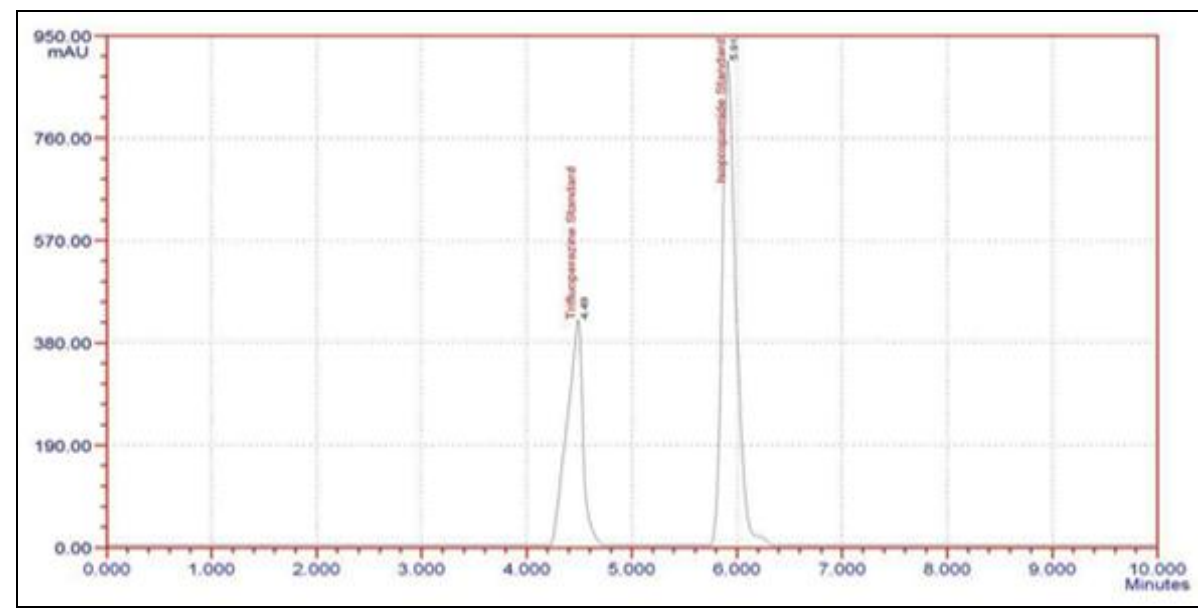

FIG. 2: STANDARD CHROMATOGRAM

Method Validation: System suitability parameters like number of theoretical plates $(\mathrm{N})$, peak asymmetry factor (As), resolution etc., were studied in the developed method. The results are given in Table 2. 
TABLE 2: SYSTEM SUITABILITY RESULTS

\begin{tabular}{|c|c|c|}
\hline S.no & Parameter & Results \\
\hline 1 & $\begin{array}{l}\text { Active pharma } \\
\text { ingradient } \\
\text { concentration }\end{array}$ & $\begin{array}{l}\text { Trifluoperazine }-6 \mu \mathrm{g} / \mathrm{mL} \\
\text { Isopropamide }-15 \mu \mathrm{g} / \mathrm{mL}\end{array}$ \\
\hline 2 & Retention time & $\begin{array}{c}\text { Trifluoperazine }-4.49 \mathrm{~min} \\
\text { Isopropamide }-5.91 \mathrm{~min}\end{array}$ \\
\hline 3 & Resolution & $\begin{array}{c}\text { Trifluoperazine }-\ldots \ldots . \\
\text { Isopropamide }-6.93\end{array}$ \\
\hline 4 & Area & $\begin{array}{c}\text { Trifluoperazine }-391886 \\
\text { Isopropamide - } 747944\end{array}$ \\
\hline 5 & $\begin{array}{l}\text { Theoretical } \\
\text { plates }\end{array}$ & $\begin{array}{c}\text { Trifluoperazine }-3979 \\
\text { Isopropamide }-6460\end{array}$ \\
\hline 6 & Tailing factor & $\begin{array}{c}\text { Trifluoperazine }-0.91 \\
\text { Isopropamide }-1.62\end{array}$ \\
\hline
\end{tabular}

Linearity was established by least squares linear regression analysis of the calibration curve. The calibration curves were linear over the concentration range of $2-12 \mu \mathrm{g} / \mathrm{mL}(\mathrm{y}=37333 \mathrm{x}+$ 17107) for trifluoperazine and $5-30 \mu \mathrm{g} / \mathrm{mL}(\mathrm{y}=$ $45766 x+86516)$ for isopropamide. Peak areas were plotted versus respective concentrations and linear regression analysis was performed on the resultant curves. Correlation coefficients were found to be 0.998 and 0.999 for isopropamide (Fig. 3) and trifluoperazine (Fig. 4) respectively. The results are given in Table 3.

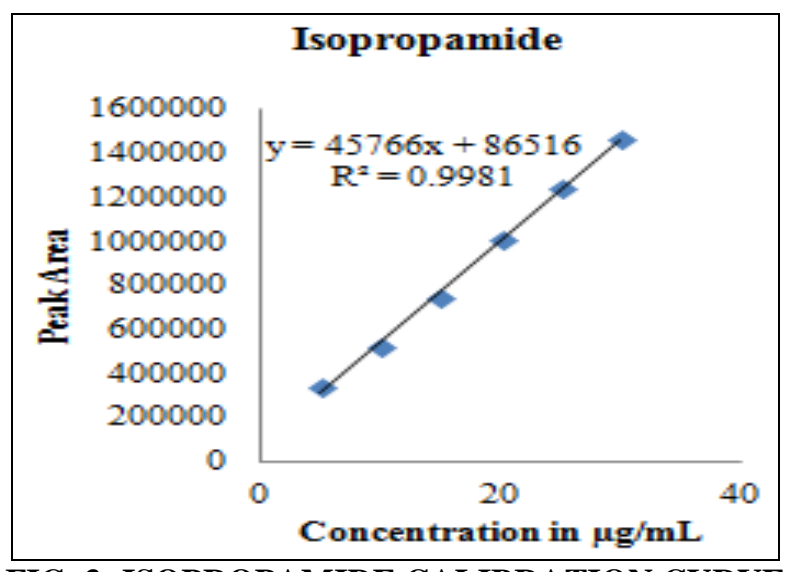

FIG. 3: ISOPROPAMIDE CALIBRATION CURVE

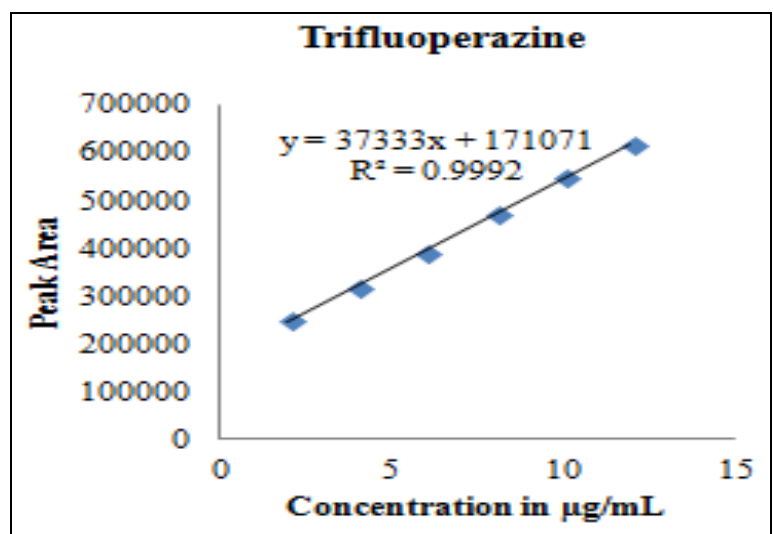

FIG. 4: TRIFLUOPERAZINE CALIBRATION CURVE
The precision of the analytical method was studied by multiple sampling of the homogenous sample. The precision was done at two levels (intraday and inter day). Intraday precision was done by analyzing the intermediate concentration of each drug for six times. Interday precision was measured over three consecutive days for the same drug concentrations for six times. The \%RSD values were calculated for each of them. The intraday precision study for six sample preparations in marketed samples showed a RSD of 1.34 and 0.42 for trifluoperazine and isopropamide respectively. For the interday precision, a study carried out by the same analyst working on different days. The inter day RSD values (For Standard) were found to be 0.90 and 0.65 for trifluroperazine and isopropamide respectively. The same study was carried out by different analysts ( $\mathrm{n}=6$ number of samples per analyst) obtaining a RSD of 0.99 and 0.70 (ruggedness) respectively for trifluoperazine and isopropamide. These results show that the proposed analytical technique has a good intermediate precision. Results are summarized in Table 3. Robustness of the method was determined by small deliberate changes in detector wavelength, mobile phase $\mathrm{pH}$ and mobile phase ratio. The content of the drug was not adversely affected by these changes as evident from the low value of relative standard deviation indicating that the method was rugged and robust.

Recovery studies were carried out by applying the method to drug sample to which known amount of standard trifluoperazine and isopropamide corresponding to $50 \%, 100 \%$ and $150 \%$ of label claim had been added. At each level of three determinations were performed. LOD and LOQ decide about the sensitivity of the method. LOD is the lowest detectable concentration of the analyte by the method while LOQ is the minimum quantifiable concentration. LOD and LOQ were calculated from standard calibration curves. The proposed procedures were successfully applied for the simultaneous estimation of trifluoperazine and isopropamide in the formulation and the drug contents in each sample were calculated by comparison with the appropriate standard solution of the drug. The results obtained were in agreement with label claim. The summaries of results of analysis are given in Table 3 . The chromatogram for formulation was shown in Fig. 5. 
TABLE 3: SUMMARY RESULTS

\begin{tabular}{ccc}
\hline Parameter & \multicolumn{2}{c}{ Results } \\
\cline { 2 - 3 } & Trifluoperazine & Isopropamide \\
\hline Linearity range( $\mu \mathrm{g} / \mathrm{ml})$ & $2-12$ & $5-30$ \\
Correlation coefficient & 0.999 & 0.998 \\
Slope & 37333 & 45766 \\
Intercept & 17107 & 86516 \\
LOD $(\mu \mathrm{g} / \mathrm{ml})$ & 0.01 & 0.03 \\
LOQ $(\mu \mathrm{g} / \mathrm{ml})$ & 0.05 & 0.10 \\
Recovery $(\%)$ & & \\
50 & 99.95943 & 99.87836 \\
100 & 99.74691 & 99.54829 \\
150 & 100.197 & 100.5895 \\
Precision $(\mathrm{RSD} \%)$ & & \\
Intraday(n=6) & 1.34 & 0.42 \\
Interday(n=6) & 0.90 & 0.65 \\
Ruggedness(n=6) & 0.99 & 0.70 \\
Robustness $(\%$ Change) & & \\
Mobile Phase 1[Methanol: Acetonitrile: Water $34: 35: 30(\mathrm{v} / \mathrm{v})]$ & 0.27636 & 0.36473 \\
Mobile Phase 2[Methanol: Acetonitrile: Water $45: 25: 30(\mathrm{v} / \mathrm{v})]$ & 0.48458 & 0.06137 \\
pH 1 (5.5) & 0.64151 & 1.095 \\
pH 2 (5.7) & 0.32331 & -1.692 \\
Wave Length 1 (235nm) & 0.84463 & -0.2004 \\
Wave Length 2 (245nm) & 1.42006 & -0.0471 \\
Formulation assay & 98.0354 & 99.58647 \\
\hline
\end{tabular}

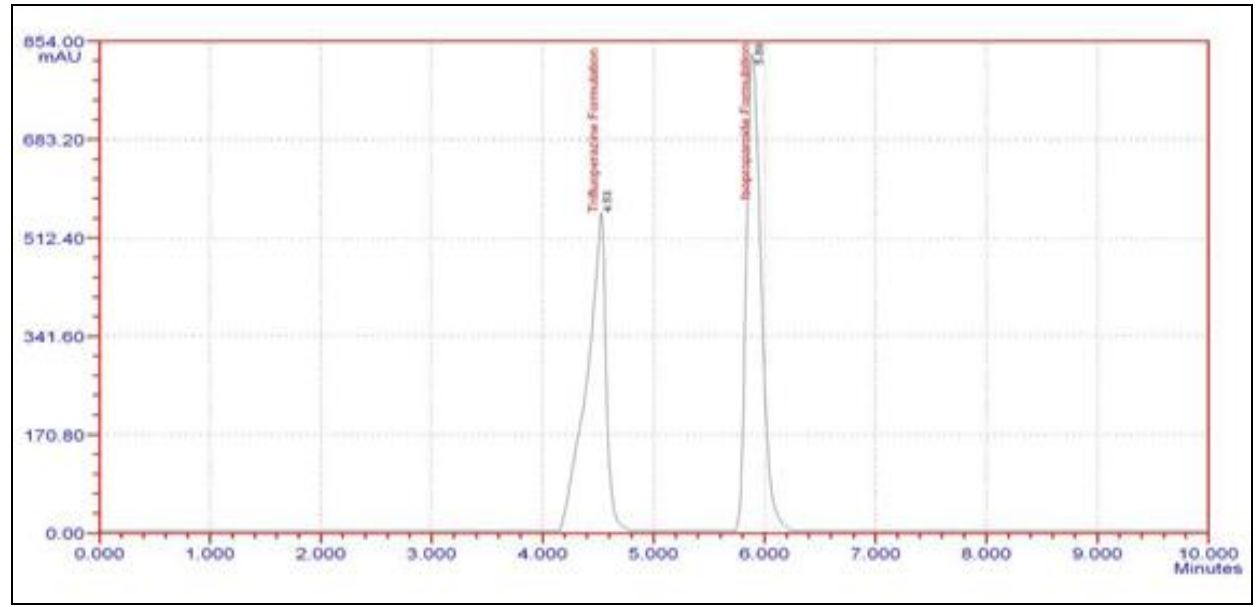

FIG. 5: FORMULATION CHROMATOGRAM

Forced degradation Studies: Stability of trifluoperazine and isopropamide was carried out by forced degradation study. The chromatograms of samples degraded with acid, base, hydrogen peroxide and light showed well separated spots of pure trifluoperazine and isopropamide as well as some additional peaks at different $\mathrm{R}_{\mathrm{t}}$ values.

The chromatogram of acid degradation study showed additional peak at $\mathrm{R}_{\mathrm{t}}$ value $3.44,6.86$ and 8.59 min (Fig. 6) and 3.46, 5.35, 8.58min in base degraded samples. The sample degraded with hydrogen peroxide (Fig. 7) showed additional peak at $\mathrm{R}_{\mathrm{t}}$ value of 5.36 and $7.20 \mathrm{~min}$. The sample degraded in dry heat showed additional peak at $R_{t}$ 2.55, 7.18 and $8.58 \mathrm{~min}$ and in UV light at $\mathrm{R}_{\mathrm{t}} 3.41$, 5.15, 7.77 and 8.78min (Fig. 8).

The percentage recovery in the degradation studies was also calculated for isopropamide and trifluoperazine in the optimized method. More than $90 \%$ recovery was obtained for both the drugs in all the degradation conditions except trifluoperazine in base degradation $(88.97 \%)$. Hence the method was stable in all the stress degradation conditions studied. The results were given in Table 4. 
TABLE 4: FORCED DEGRADATION STUDIES RESULTS

\begin{tabular}{cccccccc}
\hline Condition & No of additional & \multicolumn{3}{c}{ Isopropamide } & \multicolumn{3}{c}{ Trifluoperazine } \\
\cline { 3 - 8 } & peaks observed & $\begin{array}{c}\text { Area } \\
\text { Obtained }\end{array}$ & $\begin{array}{c}\text { \% } \\
\text { Recovered }\end{array}$ & $\begin{array}{c}\text { \% } \\
\text { Degradation }\end{array}$ & $\begin{array}{c}\text { Area } \\
\text { Obtained }\end{array}$ & $\begin{array}{c}\text { \% } \\
\text { Recovered }\end{array}$ & $\begin{array}{c}\text { \% } \\
\text { Degradation }\end{array}$ \\
\hline Acid & & 371156 & 94.7102 & 5.289804 & 704763 & 94.22671 & 5.773293 \\
Aqueous & 1 & 368130 & 93.93803 & 6.061967 & 732344 & 97.91428 & 2.085718 \\
Base & 3 & 353735 & 90.26477 & 9.735229 & 665429 & 88.96776 & 11.03224 \\
Peroxide & 2 & 379541 & 96.84985 & 3.150151 & 726471 & 97.12906 & 2.870937 \\
Thermal & 3 & 365219 & 93.19521 & 6.804785 & 707011 & 94.52726 & 5.472736 \\
UV & 4 & 376179 & 95.99195 & 4.008053 & 689007 & 92.12013 & 7.879868 \\
Light & 2 & 382587 & 97.62712 & 2.372884 & 703507 & 94.05878 & 5.94122 \\
\hline
\end{tabular}

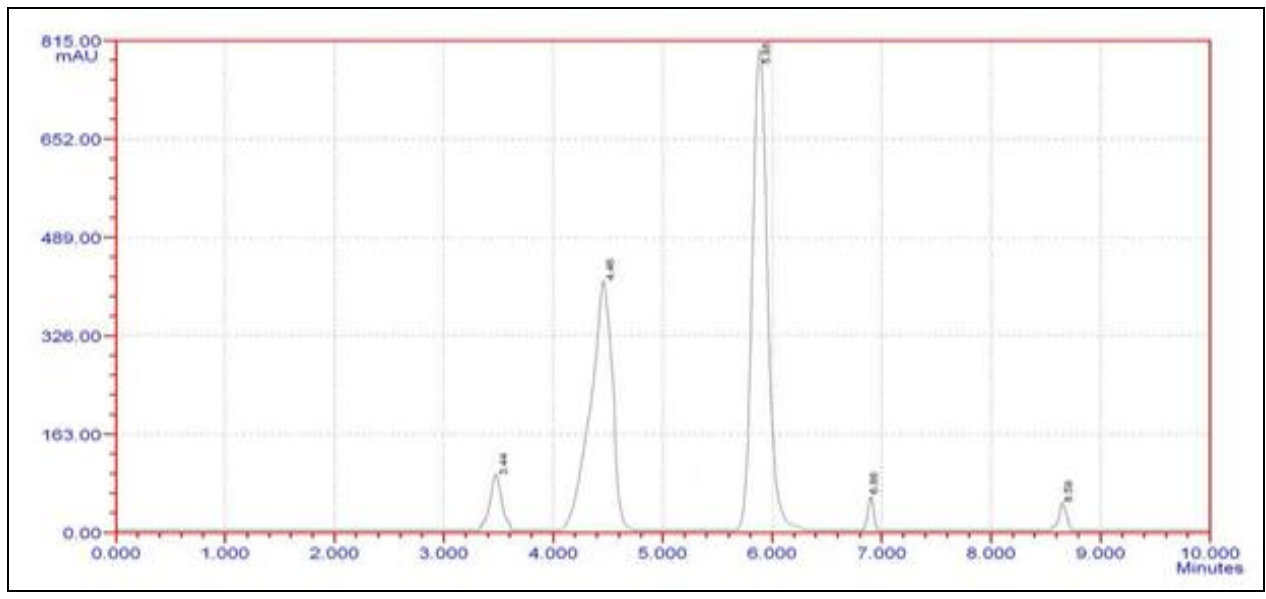

FIG. 6: ACID DEGRADATION CHROMATOGRAM

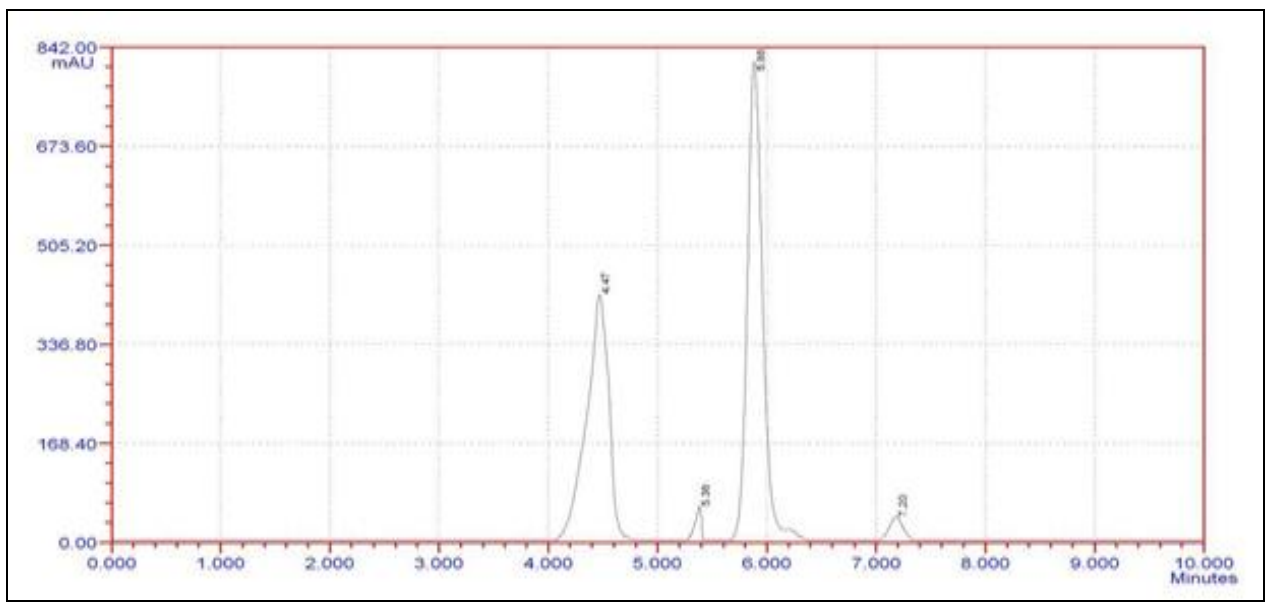

FIG. 7: PEROXIDE DEGRADATION CHROMATOGRAM

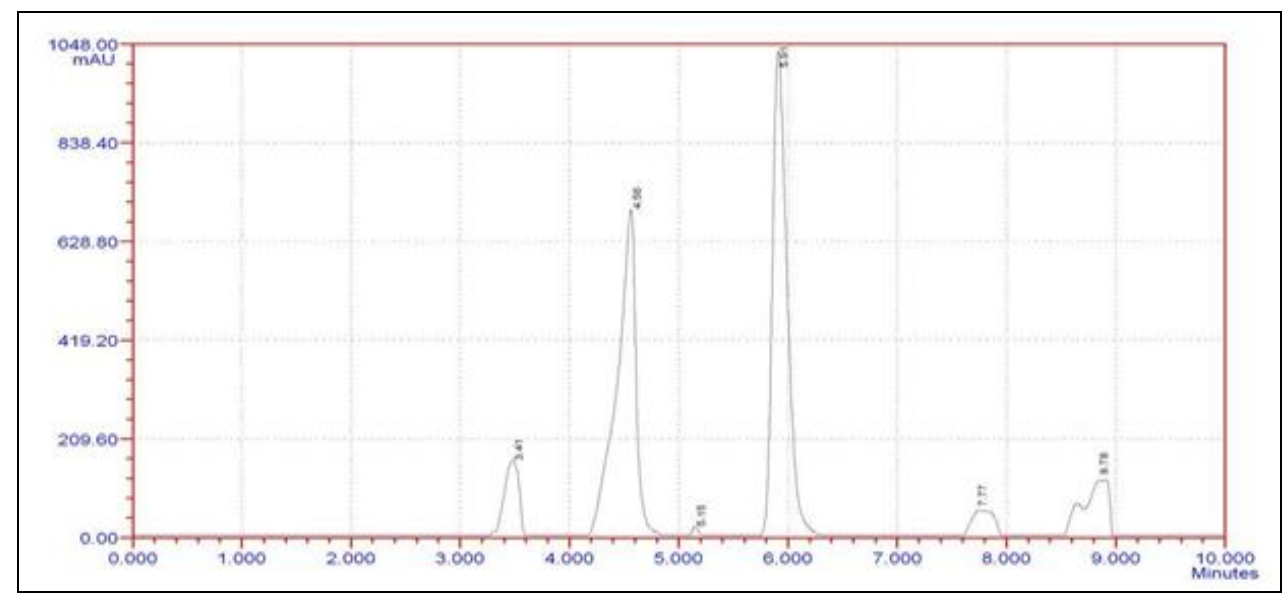

FIG. 8: UV LIGHT DEGRADATION CHROMATOGRAM 
CONCLUSION: An isocratic stability-indicating HPLC-UV method has been developed for the estimation of isopropamide and trifluoperazine in bulk and pharmaceutical formulations. Separation was achieved on Waters C-18 (250mm x 4.6mm, $5 \mu \mathrm{m})$ column using mobile phase of methanol, Acetonitrile and water in the ratio of 40:30:30 (v/v) at a flow rate of $0.9 \mathrm{~mL} / \mathrm{min}$. UV detection was carried at a wavelength of $240 \mathrm{~nm}$. The method is successively applied to pharmaceutical formulation. No chromatographic interferences from the tablet excipients were found. The suitability of this HPLC method for quantitative determination of the compounds is proved by validation in accordance with the requirements of ICH guidelines. Statistical data showed that RP-HPLC methods are robust, rugged, sensitive and accurate as compared to existing analytical methods.

ACKNOWLEDGEMENT: I am thankful to the management of KBN PG College for their consistent support and encouragement.

\section{CONFLICTS OF INTEREST: Nil}

\section{REFERENCES:}

1. Rex William Cowdry and David L. Gardner: Pharmacotherapy of Borderline Personality Disorder Alprazolam, Carbamazepine, Trifluoperazine, and Tranylcypromine. Arch Gen Psychiatry 1988; 45 (2): 111119.

2. David S. Baldwin and Polkinghorn: Evidence-based pharmacotherapy of generalized anxiety disorder. International Journal of Neuropsy chopharmacology 2005; 8: 293-302.

3. Tang L, Shukla PK and Wang ZJ: Trifluoperazine, an orally available clinically used drug, disrupts opioid antinociceptive tolerance". Neuroscience Letters 2006; 397 (1-2): 1-4.

4. Ballard C, Lana MM, Theodoulou M, Brayne C, and A Randomised, Blinded, Placebo-Controlled Trial in Dementia Patients Continuing or Stopping Neuroleptics. PLoS Medicine 2008; 5 (4):

5. Huerta-Bahena J, Villalobos-Molina R and García-Sáinz JA: Trifluoperazine and chlorpromazine antagonize alpha 1- but not alpha2- adrenergic effects. Molecular Pharmacology 2009; 23 (1): 67-70.

6. Seeman $\mathrm{P}$, Lee $\mathrm{T}$, Chau-Wong $\mathrm{M}$ and Wong $\mathrm{K}$ : Antipsychotic drug doses and neuroleptic/dopamine receptors". Nature. 1976; 261 (5562): 717-9.

7. Creese I, Burt DR and Snyder SH: Dopamine receptor binding predicts clinical and pharmacological potencies of antischizophrenic drugs. The Journal of Neuropsychiatry and Clinical Neurosciences 2009; 8 (2): 223-6.

8. Ebadi, Manuchair S: Trifluoperazine Hydrochloride. CRC desk reference of clinical pharmacology (illustrated ed.). CRC Pres.1998.
9. Marques LO, Lima MS and Soares BG: Marques, Luciana de Oliveira, ed. Trifluoperazine for schizophrenia. Cochrane Database of Systematic Reviews 2004; (1).

10. Seeherman R, Isopropamide iodide: a long-acting anticholinergic. Del Med J 1957; 29(10): 265-9.

11. Boss EG Jr and Buchanan GC: Effect of isopropamide iodide on basal gastric secretion in the human. Gastroenterology 1957; 33(5): 730-6.

12. Suman Pattanayak and Ash Rani. Y: A Novel RP-HPLC Method Development and Validation for Simultaneous Estimation of Trifluoperazine and Isopropamide in Tablet Dosage Form. International Journal of Pharmaceutical Sciences and Drug Research 2015; 7(1): 105-109.

13. Navyasri D, Ramamohan Reddy T, Ajitha A and Uma Maheshwara Rao V: Method development and validation for the simultaneous estimation of trifluoperazine and isopropamide in tablet dosage form by RP-HPLC. International Journal of Pharmaceutical Research \& Analysis 2014; 4(8): 449-455.

14. Sejal K. Patel and N. J. Patel: Simultaneous RP-HPLC estimation of Trifluoperazine Hydrochloride and Chlordiazepoxide in tablet dosage forms. Indian Journal of Pharmaceutical Sciences 2009; 71 (5): 545-547.

15. Ankit B. Chaudhary, Ruchi J. Raval, KiranVaghela and Ekta Patel: Development and validation of analytical method for simultaneous estimation of chlordiazepoxide, trifluoperazine hydrochloride and trihexyphenidyl hydrochloride in tablet dosage form. International Bulletin of Drug Research 2016; 6(10): 1-16.

16. Sree Vidya Parvataneni and Pathuri Jnana Nagarjuna: Development and validation for the simultaneous determination of trifluoperazine hydrochloride and trihexyphenidyl hydrochloride in a solid oral dosage form by RP-HPLC. World Journal of Pharmacy and Pharmaceutical Sciences 2014; 3(10): 1021-1031.

17. Abd-El-Hamid N. Ahmed: Simultaneous Determination of Phenylpropanolamine Hydrochloride and Isopropamide in Capsule by High Performance Liquid Chromatography Using Crownpak Column. Analytical Letters 1993; 26(6): 1153-1162.

18. Sejal K. Patel and N. J. Patel: Simultaneous RP-HPLC Estimation of Trifluoperazine Hydrochloride and Chlordiazepoxide in Tablet Dosage Forms. Indian J Pharm Sci 2009; 71(5): 545-547.

19. ZuhairA-A. Khammas and Rana Abbas Rashid: Mutual Determination of Trifluoperazine Hydrochloride and Vanadium (V) Ions in Real Matrices by Visible Spectrophotometry after Cloud Point Extraction. Science Journal of Analytical Chemistry 2015; 3(5): 61-70.

20. Maadh $\mathrm{T}$ and Abdurahman and Kamal M, Mahmoud: Spectrophotometric Determination of Trifluoperazine Hydrochloride Using Oxidative Coupling Reaction. International Journal of Innovative Research in Technology \& Science 2016; 4(6): 23-27.

21. Bhaskar Reddy CM, Subba Reddy GV and Ananda Kumar Reddy N.: Development and validation of UV Spectrophotometric method for determination of Trifluoperazine Hydrochloride in bulk and pharmaceutical dosage form. International Journal of Scientific and Research Publications 2012; 2(8): 1-5.

22. Abbas SS, Zaazaa HE, Abdelkawy $M$ and Abdelrahman MM: Spectrophotometric determination of isopropamide iodide and trifluoperazine hydrochloride in presence of trifluoperazine oxidative degradate. Drug Test Anal 2010; 2(4): 168-81. 
23. Nief Rahman Ahmed: Ultraviolet Spectrophotometric Determination of Trifluoperazine. $\mathrm{HCl}$ in Pharmaceutical Preparations and Environmental Wastewater Samples: Application to Content Uniformity Testing, Research and Reviews. Journal of Pharmaceutical Analysis 2014; 3(2): 30-34.

24. ICH Validation of Analytical Procedures: Text and Methodology Q2 (R1). International Conference on Harmonisation 2005.
25. ICH Stability Testing: Photo Stability Testing of New Drug Substances and Products Q1B. International Conference on Harmonisation 2005.

26. ICH Stability Testing of New Drug Substances and Products Q1A (R2). International Conference on Harmonisation 2005.

\section{How to cite this article:}

Kishore MS and Rambabu C: Development and validation of a stability indicating HPLC method for the simultaneous analysis of isopropamide and trifluoperazine in fixed-dose combination tablets. Int J Pharm Sci Res 2017; 8(12): 5178-85.doi:10.13040/IJPSR.0975$8232.8(12) .5178-85$.

All @ 2013 are reserved by International Journal of Pharmaceutical Sciences and Research. This Journal licensed under a Creative Commons Attribution-NonCommercial-ShareAlike 3.0 Unported License.

This article can be downloaded to ANDROID OS based mobile. Scan QR Code using Code/Bar Scanner from your mobile. (Scanners are available on Google Playstore) 